\title{
Refusing borders: The consumption of co-working space and lifestyle
}

\author{
Syifanie \\ Graduate Student of Media and Cultural Studies Program, The Graduate School of \\ Universitas Gadjah Mada. Jalan Teknika Utara, Pogung, Mlati, Sleman, Yogyakarta, \\ Indonesia, 55281 \\ *e-mail: syifanie.alexander@gmail.com
}

\begin{abstract}
Co-working space is an alternative workspace, which offers different concept and spirit from offices in general. Co-working space is aimed to workers who need a flexible place and time to collaborate and expand their network. As a social space, co-working space cannot be separated from the growth of millennial generation as freelancers, who entered the labor market since 2000's. This research is aimed to analyze the consumption practice of co-working space's user. There are two chosen users of co-working space located in Jakarta that are used as subjects in this research by interview. Using Henri Lefebvre's theory about production of space, this research shows that: 1) there is a shift in meaning of work, from duty-ethic to fun-ethic 2) millennial generation's competence of information and communication technology makes it possible for them to do creative work with no limit of time. Flexibility becomes lifestyle. Blurred line between work time and leisure time is a privilege that can't be owned by other workers. In the end, it is a strategy to create a social distinction, that co-working space's users are different from workers in general.
\end{abstract}

\section{Keywords}

consumption practice, co-working space, freelancer, lifestyle, social distinction

\section{Introduction}

Co-working space is a shared working space. But, more than just physical space, co-working space is an alternative working space that offers a different concept and spirit from the common offices. According to Co-working Wiki, co-working space is simply a space where independent workers $^{1}$-and they who have flexibility-choose working together, rather than alone. The term co-working, became known since 2005 when Brad Neuberg built Hat Factory in San Francisco (Waters-Lynch et al., 2016). The key point that differs coworking space is in collaboration, community, accessibility, openness, and sustainability - which are the core values or value proposition of co-working space (Jones et al., 2009, p. 8). As stated by Capdevila

\footnotetext{
${ }^{1}$ Workers in question are freelancers, small-scale entrepreneurs and startups. Working professions are diverse, but they usually work in the creative or IT fields, such as authors, graphic designers, programmers, software developers, and so on.
} 
(2014), "Co-working spaces distinguish themselves from mere shared offices by focusing on the community and its knowledge sharing dynamics ... co-working spaces are defined as localized spaces where independent professionals work sharing resources and are open to share their knowledge with the rest of the community" (p. 5). Apart from the facilities like tables, chairs, meeting room, and space for events, other facilities that are usually offered are internet connection (high speed wi-fi), private locker, printing services (printer, scanner, photocopier) and other office supplies. Often unforgotten is a cafe or a pantry to make your own coffee.

According to research from The Global Co-working Survey, the number of co-working space continues to increase. By 2015, there are about 8700 co-working space in the world. In 2016, this number increased to 11300 co-working space. As of October 31,2017 , this number is increasing, accounting for approximately 13800 co-working spaces scattered around the world (Foertsch, 2017).

In Indonesia, the term co-working space may not be as popular yet. Referring to the Mild Report by Tirto.id, the concept of co-working was applied by the youth in Bandung in 2010. Yohan Totting was the pioneer. In November 2010, Yohan found Hackerspace Bandung. The idea of creating a co-working space came up after Yohan visited Hackerspace Singapore which was one of successful co-working spaces (Kresna, 2016). As far as the authors have found, there has not been much research on co-working space in Indonesia. The latest source is from Susanti \& Hermansah (2017), which shows extreme growth. According to Perkumpulan Co-working Indonesia and Lab Kinetic, in the last three years the growth of coworking space in Indonesia increased by $410 \%$. As of July 2017 there are 123 co-working space in 25 locations throughout Indonesia, mostly in Jakarta (38 spaces) and Bandung (19 spaces). In addition, coworking space is spread in cities such as Bekasi, Bogor, Depok, Serpong, Demak, Jember, Malang. Outside Java and Bali, co-working space can be found in Medan, Padang, Makassar, Samarinda, Manado, Palembang (Susanti \& Hermansah, 2017). Of course, these data need to be suspected and traced further. However, at least this data can be used as a temporary reference that the growth of co-working space in Indonesia so rapidly.

The growth of co-working space is not disconnected from the context around it. The emersion of freelance workers are in parallel with the emersion of co-working space trend. Among freelance workers are the generation deined as millenials. The millenials are the generations born after the end of 1980s until 1997. These are the youth that entered the labor market in the 2000s. One of the main characteristics of millenials is the qualified mastery of information and communication technology (ICTs) and that they are used to social media (Deal et al., 2010).

Since 2014, the proportion of freelancers in Indonesia increases every year (Gerintya, 2017). Looking at the opportunities of freelancers and the growth of co-working space in Indonesia, the researcher is interested to research this phenomena furthermore. In this article, the researcher probes in space consumption level, how freelancers interpret co-working space that is assumed to be part of certain lifestyle-where consumption is more than just its benefits, it is the symbolic value or indication shown. The question of this research is "how practice of space consumption works within the users of co-working space". Lefebvre's idea of the production of social space (The Production of Space) will be used to help researcher elaborate the consumption practices of co-working space users.

Henri Lefebvre states that space cannot be separated from the social reality around it. According to Lefebvre, spatial space production will affect the mentality of its inhabitants, thus creating what is called the production of social space (Pamungkas, 2016). Lefebvre proposes a triadic concept-to avoid dichotomous thinking - that is, spatial practice, the representation of space and the representational space (Lefebvre, 1991, pp. 38-39). Spatial practice (perceived space) is social practice that is linked to the sociohistorical relation of a space (also known as perceived space). The representation of space (conceived space) is the normative space, the ideal space, the conceptual space formulated and conceptualized its makers such as architects, planners, technocrats, civil engineers and government. Representational space (lived space) is a space directly occupied by people and its users (also known as lived space). These concepts are then referred to as the practice of producing human space. By using the triadic concept of Lefebvre, this paper seeks to see how individuals interpret the space.

\section{Methods}

This research was conducted by ethnography method through interviews and observations. The informants consisted of two users of co-working space which located in Jakarta, i.e. Ani (28 y.o.) who is working at ke:kini ruang bersama \& Block 71 and Budi (30 y.o.) who is working at Freeware Labs Kemang. 
The author uses a pseudonym in this study to maintain the confidentiality of the informants' identity. These co-working space users are regulars, at least more than three times they come and work in co-working space per month.

\section{Results and Discussions}

Ani is a worker at Viddsee.com, a Singapore-based startup. She is a writer on Viddsee.com, a 'Buzzer' for Viddsee.com Indonesia. Viddsee.com is an online video platform (website) that presents Asian short films. Launched in 2013, Viddsee.com online video platform has garnered over 500 million users worldwide by specializing in the Southeast Asian short film market (Kolesnikov, 2016). Ani started working in Viddsee.com since June 2015, initially as a freelancer there. Until in November of that year, Ani started working full-time. Previously, she worked at a beauty school company for $2 \mathrm{yr}$., but she decided to quit and choose to work in Viddsee.com because she did not like strict corporate hours (working from 9 a.m. to 5 p.m.).

"I'm not a regular person, so it's hard to pursue a 9 (a.m.) to 5 (p.m.) rhythm. My brain is also more active at night."

Although almost 2 yr. working in Viddsee.com, only since September 2016 Ani actively worked in coworking space. Since then, Ani often used co-working space, in a week approximately she spent four days to work there. Ani often worked in "ke:kini", one of co-working space in Cikini, Central Jakarta. However, since approximately May 2017, Ani decided to move to another co-working space that is "Block 71". Block 71 is located in Kuningan, Central Jakarta and just opened in Indonesia, it is a branch of Block 71 in Singapore.

Budi is a founder of a startup called Konserku.com—previously named Konsatoo. Konserku.com is a website that hosts music and music concerts connoisseurs to realize their dream concert by gathering fellow fans to support their favorite artists to perform in their respective cities. Previously he worked at JP Morgan's company in Singapore, less than a year (10 months). Even so, while studying at the National University of Singapore (NUS), he interned and did some projects at an entertainment company (part of Universal Studios), where his interest in music develops.

Budi started working in co-working space since August 2016, the year where Konserku.com was launched officially. The reason he quit his previous job was similar to Ani's. Budi prefers work flexibly, "I just cannot work in the office everyday." said Budi.

Budi heard the term co-working space long ago, around 2009. Before working in "Freeware Labs Kemang" since August last year, he tried working several times in co-working space like Conclave, EV Hive, and Comma-all in Jakarta. However, only Freeware Labs Kemang has so far answered his needs.

Ani and Budi have their respective reasons regarding their motivation to work in co-working space. For Budi, interaction is the main variable that he hopes to get in co-working space. The interaction allows for collaboration between users, either for mutual input, or for other opportunities.

The drive to work in co-working space is an internal boost within Budi. Meanwhile, what made Ani initially start working in co-working space came from factors outside of herself. She admitted, her need to work in co-working space is the provision of facilities from Viddsee.com. Viddsee.com stands in Singapore, but it is networked with other Southeast Asian countries such as Indonesia. Ani is the only representative from Indonesia who works in Viddsee.com, therefore there is no special office owned by Viddsee.com in Indonesia, apart from building cost of an office that is also considered hard for a small startup like Viddsee.com. However, to ensure the productivity of its employees, Viddsee.com finance Ani to work in coworking space. In contrast to Budi, Konserku.com is only handled by both him with his partner. So far, they both are self-financing their co-working space cost.

Apart from that, one thing that both Ani and Budi emphasize when sharing their experience is the mobility case. Of course, this is relevant to the condition in Jakarta which incidentally has the traffic problem every day. As a result, traffic is one thing that is equally important for both of them in determining the location of co-working space. Ani prefers to work for the first time in ke:kini because it's location in Cikini (Central Jakarta) close to her residence in Salemba (Central Jakarta).

Also, she finally moved to Block 71 in Kuningan (South Jakarta) because for her Kuningan is still quite easy to be reached by her. Kuningan area is also the center of the business district, where meetings are often held with various parties or clients. The same thing is also recognized by Budi, that choosing Kemang 
(South Jakarta) is because Kemang has easy access to the central areas of business meetings. In addition, the main reason is also the case of residence, he lives in Pasar Minggu (South Jakarta) where it is close to Kemang, this is because Budi can not afford to go through traffic jams for too long, 45 minutes is his limit. Mobility becomes a significant factor. That is why, co-working space is spread over the strategic points of urban space.

\subsection{A Consumption Practices of Space}

\subsubsection{The presence of co-working space}

Since the 1970s, social and cultural theories have begun to consider the issue of space and place. Although looks the same, space and place are two different concepts. According to Giddens, space refers to an abstract idea, a blank or dead space, filled with places-concrete and specific. Both place and space, closely related to the social processes that construct it (Barker, 2008).

Co-working space as a social space is formed by social-cultural reality that surrounds it, that is the growth of millennial generation as freelancers and the presence of information and communication technology (ICTs). In the 2000s, millennials have entered the labour market. However, the presence of ICTs has changed the labour market because mastery over technology and social media allows millennial generations to work virtually without physical presence. Gerintya (2017) in his research also shows that millennials prefer working hours and flexible workplaces. Work as a freelancer becomes the right choice to fulfil that desire.

The development of ICT also allows people to master a job outside their field. According to an interview conducted by Kirnandita (2017) on the Tirto.id website, the habit of accessing information from advanced communication devices that millennials possess, allows them to gain a wide range of knowledge without having an academic background in studies to master a particular skill. This is what Kirnandita (2017) mentioned as "the starting point of the availability of variety of jobs and opportunities that are not demanding of physical appearance between millennial freelancers and recruiting companies". The growth of these freelancers indeed affects the landscape of business and worker culture. All of these spatial practices (perceived space) ultimately produce co-working space as a social space.

The rise of business models like co-working space is also influenced by the habit of freelancers who work in cafes or other public spaces. In general, cafes are an option for freelancers. By buying a cup of coffee for example, these freelancers can sit for hours in a cafe working with their devices on a comfortable sofa provided by the cafe. However, it is often that the atmosphere in cafes or other public spaces is not work friendly. Distractions like noises and technical matters become problems that hinders with concentration to work. This is what justifies co-working space a best place to work. Not only providing spaces appropriate for work, co-working space also promises interactions between varying fellow freelancers. Co-working space is a perfect and comfortable place to work (conceived space).

Furthermore, this diverse interaction of freelancers are expected to become a community, as a result of the space they create. The community here means a group of people-in this case, the users of co-working space-which consists of various backgrounds of knowledge and work, they collaborate to produce something positive. The results of these networks can be a collaboration project, establishing a new startup for example, or simply providing input or helping to conceptualize their respective projects. Chairwoman of Perkumpulan Co-working Indonesia, Faye Alund, told that the spirit of co-working space is all about community. Faye said (Susanti \& Hermansah, 2017), "It should be understood that co-working is not selling the space but the community. Communities that rely on connectivity to collaborate. Co-working evolved because of the same DNA, which is innovation, idea sharing, and economic sharing. So this is a new way of working".

\subsubsection{Between Interaction and Distraction}

Budi expressed his opinion about the concept of co-working space as he had known. From the beginning, he has understood and believed that the essence of co-working space is interaction. "Co" in the co-working space, as he stated, is collaboration and community. He knew the concept from the publications about coworking space. Indiana has same comprehension as Budi. Co-working space is not just a place to work, but it offers networks. "Who knows we can make something from here," Ani said. 
However, in fact, the concept of co-working space that offered by the owner (conceived space) is different from the reality that faced by users (lived space). Many factors influence, both internal and external. There are some cases to explain it.

In the first case, Budi and Ani experienced interaction. Budi experienced that the concept of collaboration is well manifested in the space of Freeware Labs Kemang. Budi interpreted the hall or lounge of Freeware Labs Kemang as a space to interact between co-working space's users as his explanation, "because we can share and give suggestion and support ... interaction is important because our friends (coworking space's users) is potential as our targeted customer in the future."

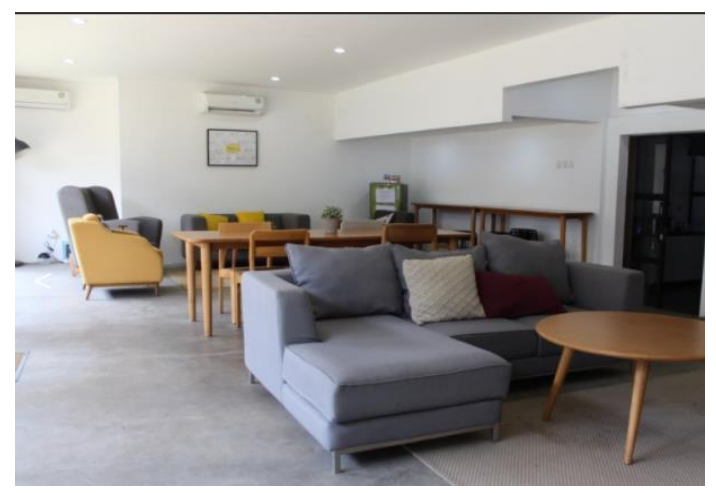

Fig. 1 Lounge in Freeware Labs Kemang (Freeware Spaces, 2015) ${ }^{\mathrm{i}}$

Budi gave his example that several times he bought a product from Maskoolin.com—one of a Freeware Labs Kemang's user. He also gave feedback to Maskoolin.com about their website's trouble. Budi also was helped by another co-working space's user to make a video teaser for his project at Konserku.com. There are some interactions that result in collaboration there.

From Budi's story, lunch time is the moment to interact each other. Cigarettes became important because, as Budi said, smoking activity in the outdoor lounge can cultivate their relationship. From the smoking talk and lunch, they can interact with each other. Lounge is a space that can make the dialogue between them is possible. The concept of the dynamic space is fit with the concept that offered by coworking space (conceived space).

Ani has same experience as Budi. She could get acquainted with new people while she worked at ke:kini although there is a few. Ani also could talk or exchange ideas to the manager of ke:kini. The manager of ke:kini is her friend. Friendship factor help Ani to get acquainted and express her ideas easier. It means that there is other factor beside the space (external) that influence Ani's practice of consumption in the coworking space.

In the second case, not all interaction is happened in co-working space. Before decided to work at Freeware Labs Kemang, Budi tried to work at some co-working spaces in Jakarta, like Conclave, EV Hive, and Comma. The three co-working space could not cause interaction in the designed space.

In the Block 71, Ani felt isolated and lonely. Flexible working hours cause interaction between Block 71 users is difficult. In fact, most users came to Block 71 in the common working hours (9 a.m. to 5 p.m.). Different schedule of the users make Ani alienated.

"In Block 71, I feel lonely because I do not know other users. The start-up that work there came with their team, so that they chat among them ... There is no one that I can talk with about my work at Viddsee.com.... It does not mean that I do not try to interact with others, but the interaction or the message is different from my expectation."

Through their experience, it can be noted that the conceived space that imagined by the owner of coworking space can be incompatible with the consumption practices of it's users. The difficulties can be happened because users have different background and field of work. Instead of collaboration with new people, co-working space users only interact with people that they knew. In the end, co-working space did not succeed in building new network or community. It is out of owner's attention.

Moreover, the next case shows that designed space as co-working space, on the contrary, become distraction. According to information from Ani, ke:kini consist of two floors with different function. The first floor is a space to meet and interact-like the lounge offered by Freeware Labs Kemang. The second floor is a quieter space that can help to concentrate. However, whichever floor of Ani is, it is disturbed by the interaction of other users, especially when she is in a virtual meeting (via Skype or video call) with her 
Viddsee.com colleagues in Singapore. Ke:kini often rented (one full floor) for certain occasions. The noise from the event is very disturbing for Ani. She had gone home early because she could not concentrate there.

"Ke:kini is an open space for chitchat and networking ... But, I was disturbed when someone suddenly laughed while I was meeting. This distraction slows down my own work."
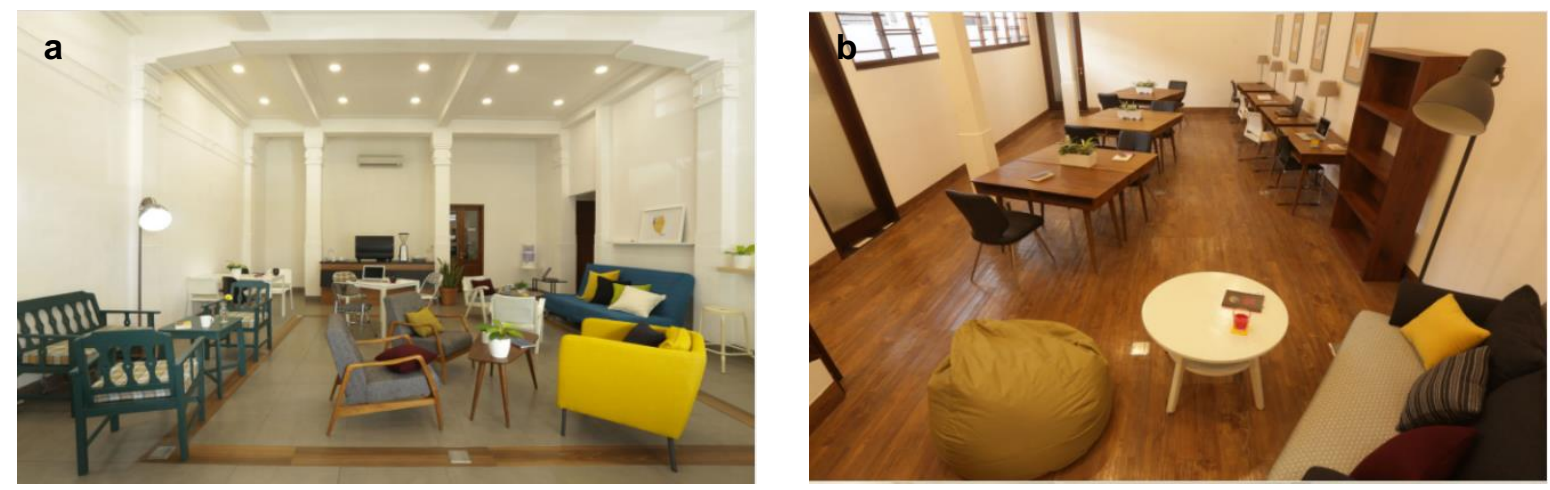

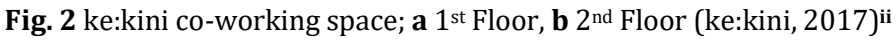

Consumption practice in co-working space is a dilemma. On the one hand users are expected to socialize, but at the same time it interferes with user privacy. Furthermore, the flexibility of working hours offered by co-working space were not used by some users, they still work with office hours in general. When flexibility is applied, the effectiveness for interaction is reduced due to the difference in working hours. These situations are paradoxical because co-working space wants to accommodate contradictory things.

\subsection{The Shifting Meaning of Work}

Flexibility is the main variable that differentiates freelancers from office workers in general. With this flexibility, the meaning of work shifts. The users of co-working space are millennials who have different working concepts. Therefore, there is no longer need to work in a conventional office like the previous generation. The phenomenon of co-working space is related to what Bourdieu (1984) said in Distinction: A Social Critique of the Judgment of Taste. The presence of $c o$-working space relates to what Bourdieu said about the emergence of new petite bourgeois with distinctive taste and cultural practice from 'the old one' or old generation. Distinction in social space is indicated by displaying different tastes from other individuals.

\footnotetext{
"The new petite bourgeoisie comes into its own in all the occupations involving presentation and representation (sales, marketing, advertising, public relations, fashion, decoration and so forth) and in all the institutions providing symbolic goods and services." (Bourdieu, 1984, p. 359)
}

Furthermore, Bourdieu describes that the emergence of the new petite bourgeoisie contributed to the shifting meaning of work from the former duty-ethic, to fun-ethic. Just as happened in the present context, the co-working space are actually created a new meaning of work. Shifting the working paradigm from the rigid tendency (working full-time from 9 a.m. to 5 p.m.) becomes flexible work. Mastery of information and technology opens opportunities for them to do their job more flexible.

Unpredictable digital jobs also began to emerge, such as social media officers, video bloggers, UX Designer, and so on. 'Creative workers' term began to be talked about and looked more interesting than office jobs. This is still related to what Bourdieu said as distinction, a kind of strategy to differentiate themselves with other individuals. All of this is ultimately a strategy to create a distinction that co-working space users differ from other workers. Flexibility becomes a lifestyle of co-working space users.

Mobility cases should also be noted. Jakarta congestion is high, especially in office hours, and this made freelancers have to negotiate with space. Finally, the flexibility of working time becomes important and necessary to avoid congestion. Mobility requires flexibility in work. That is, this mobility is also part of everyday life that becomes a lifestyle. 


\subsection{Co-working Space: Commodification of Space}

Lefebvre's concept The Production of Space suggests that, in the end, space is inseparable from economic and political relations. The presence of co-working space seems to facilitate the need for space for freelancers but actually co-working space is ultimately nothing more than a commodification of space. Spaces are commercialized, there are buying and selling transaction in co-working. The cost of each coworking space are varies, but general packages and price range offered by co-working space in Jakarta is more or less the same. There are many packages offered such as 1-Day, 7-Days, 15-Days, 30-Days, to 1-Year working. In fact, if you need to come and sit for a while, to check email or meeting with clients in a short time for example, you can choose package 2 hours walk-in there. You need to pay between fifty thousand one hundred thousand for just two hours walk-in or (twenty to five) million rupiah for 1 yr. working there. Ani and Budi must pay about (two to five) million rupiah per month. This price does not help freelancers who do not have a monthly fixed job. In this case, capitalism can survive because it actively produces and reproduces space to support its sustainability. The phenomenon of co-working space affirms that space is produced in such a way as to perpetuate power and dominance.

\section{Conclusions}

The discussion of space is not focused on physical things, but rather on how space is produced by human. Co-working space is a tangible form of how the practice of space cannot be separated from the social context that surrounds it. Flexibility in work ultimately represents the lifestyle of freelance workers from millennial generation in these days. Blurred line between working time and leisure time is a form of luxury that some workers do not have generally. All of this, by the end, is a strategy to create distinctions, that co-working space users are different from other kind of workers.

The practice of space in a co-working space cannot be separated from the power of the capitalists. This phenomenon makes us realize how freelance workers may be laborers in other forms. We are conditioned in such a way that we cannot escape from the restrictions to continue being exploited. However flexible is the autonomous choice of freelance workers as an individual, in fact working must also be in commercialized spaces, spaces that have been selected or conditioned by the capitalists. Co-working space provides convenience while simultaneously could exploit freelance workers.

\section{References}

Anonim (2015). Freeware Labs Kemang [Photograph]. Retrieved from https://www.freewarespaces.com/location/kemang

Anonim (2017). Adopsi Ruang ke:kini [Photograph]. Retrieved from http://kekini.org/acara/

Barker, C. (2008). Cultural studies: Teori \& praktik (Cultural studies: theory \& practice). Yogyakarta: Kreasi Wacana.

Bourdieu, P. (1984). Distinction: A social critique of the judgement of taste (R. Nice, Trans.). Cambridge, Massachusetts: Harvard University Press.

Capdevila, I. (2013). Knowledge dynamics in localized communities: Co-working spaces as microclusters. SSRN. Electronic Journal.

Deal, J. J., Altman, D. G., Rogelberg, S. G. (2010). Millennials at work: What we know and what we need to do (if anything). Journal of Business and Psychology, 25(2), 191-199.

Foertsch, C. (2017). More than one million people will work in coworking spaces in 2017. Deskmag, Retrieved November 25, 2017, from http://www.deskmag.com/en/the-complete-2017-coworkingforecast-more-than-one-million-people-work-from-14000-coworking-spaces-s 
Gerintya, S. (2017). Pekerja freelance milenial Indonesia didominasi pria [Freelance worker in Indonesia dominated by man]. Tirto.id. [In Bahasa Indonesia]. Retrieved April 27, 2017, from https://tirto.id/pekerja-freelance-milenial-indonesia-didominasi-pria-cnvL

Kirnandita, P. (2017). Mengapa milenial kepincut pekerjaan freelance? [Why millennials are attracted to freelance jobs?]. tirto.id. [In Bahasa Indonesia]. Retrieved April 23, 2017 from https://tirto.id/mengapa-milenial-kepincut-pekerjaan-freelance-cnca

Kolesnikov, S. J. (2016). Viddsee-an ecosystem of shared stories on film. Imda.gov.sg. tirto.id. [In Bahasa Indonesia]. Retrieved December 7, 2016, from https://www.imda.gov.sg/infocomm-and-medianews/sg-spotlight/2016/12/viddsee-an-ecosystem-of-shared-stories-on-film

Kresna, M. (2016). Melacak muasal coworking space di Indonesia (Track the origin of coworking space in Indonesia). tirto.id. [In Bahasa Indonesia]. Retrieved November 30, 2016, from https://tirto.id/melacak-muasal-coworking-space-di-indonesia-b5UK

Lefebvre, H. (1991). The Production of Space (D. Nicholson-Smith, trans.). Cambridge: Basil Blackwell, Inc.

Susanti, I., \& Hermansah (2017). Coworking space dorong pertumbuhan ekonomi kreatif (Coworking space push the growth of creative economy). koran-sindo.com. [In Bahasa Indonesia]. Retrieved November 25, 2017, from http://koran-sindo.com/page/news/2017-0806/0/1/Coworking_Space_Dorong_Pertumbuhan_Ekonomi_Kreatif

Pamungkas, A. S. (2016). Produksi ruang dan revolusi kaum urban menurut Henri Lefebvre (Production of space and urban revolution by Henri Lefebvre). Indoprogress.com. [In Bahasa Indonesia]. Retrieved January 11, 2016, from https://indoprogress.com/2016/01/produksi-ruang-dan-revolusi-kaumurban-menurut-henri-lefebvre/

Jones, D., Sundsted, T., \& Bacigalupo, T. (2009). I'm outta here: How co-working is making the office obsolete. Brooklyn: not an MBA press.

Waters-Lynch, J., Potts, J., Butcher, T., Dodson, J., Hurley, J. (2016). Co-working: A transdisciplinary overview. SRRN. Electronic Journal.

\footnotetext{
i Screen-captured from Freeware Labs Kemang website https:// freewarespaces.com/location/kemang

ii Screen-captured from ke:kini ruang bersama website http://kekini.org/acara/
} 